\title{
Material for knitwear: a new contemporary design scenario
}

\section{Conti, Giovanni Maria}

Resumen: En el contexto globalizado actual en el que la fertilización cruzada entre disciplinas y diferentes campos de proyecto se mezcla generando formas, sistemas y procesos, el diseño de Tejidos de Punto puede marcar la diferencia en la producción y en el consumo de los productos.

En realidad, son ideas reales sobre los diversos temas que caracterizan esta área. Actualmente el diseño en áreas muy específicas como diseño de tejido de punto italiano, realizado por artistas, diseñadores, hilanderos, empresas, continuamente entre la tradición y el producto manual industrial, hace de la investigación un desafío realmente complicado. En los escenarios contemporáneos el diseño de tejido de punto es un proceso complejo, que combina antiguas técnicas tradicionales de conocimiento con la experimentación y la innovación tecnológica. Es un desafío que

Cuadernos del Centro de Estudios de Diseño y Comunicación N070

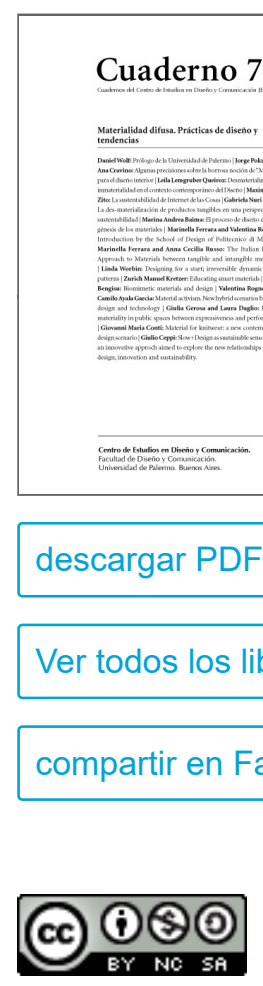

Esta obra está bajo una Licencia Creative Commons Atribución-NoComercialCompartirlgual 4.0 Internacional alimenta la curiosidad y el deseo de buscar más.

Palabras clave: Tejido de punto - fertilización cruzada - Innovación - pensamiento de diseño - hilos - materiales.

$\left.{ }^{*}\right) \mathrm{PhD}$ in Design, assistant professor at the Design Department, School of Design at the Politecnico di Milano. $\mathrm{He}$ is currently the Coordinator of Knitwear design Lab - Knitlab of the Fashion Design Degree at the Politecnico di Milano. His fields of interest are focused on contemporary design with a specialization on Knitwear and Fashion Design.

The essence and beauty of knit lies in the fact that the designer invents everything from scratch; he creates the stitch, the handle, the weight and chooses the colour, deciding on texture and shape at the same time, mastering his own finishings and detailing. (Edelkoort L., in Sissons J., 2010, Basics Fashion Design: knitwear, Ava Publishing, Lausanne)

A loose thread in a knit is not a defect but a hint of the story behind its presence (Conti G. M, 2014, p. 84). Yarn is not just a collection of fibres - it may be the element that underpins a work of art, a three-dimensional object, a product to wear. It is an element imbued with symbolic values and it is one of the first images introduced even in childhood, with the Brothers Grimm fairy tale Sleeping Beauty, in which the princess pricks her finger with a spindle, with yarn thus evoking the world of weaving, knitting, of the handmade, of tradition. Knitwear uses different types of yarn, like wool, cotton and flax, but also synthetic yarns, blends from plant or animal sources. It is perhaps one of the most ancient manual skills in the world. All women, young or old, rich or poor, single or married, have knitted something at some point, from items for a bottom drawer to small pieces for their families. 
Knitting requires yarn to be twisted in a special way, tightened at a specific point and then serial repetition of the gesture, only to stop the series with a variation, then return to the multiple reproduction of identical actions. The knitter must be able to follow a pattern. (Silvana Annicchiarico, Tramate tramate, le streghe son tornate, in Dritto Rovescio, Electa Mondadori, Milan 2009, p. 10)

Specifying that there is a difference between knitting by hand with needles, and mass production using linear artisanal or industrial machines, i.e. on a trade scale, we can say that the design challenge posed by knitting lies in understanding how a single yarn can make a desirable, comfortable and wearable garment.

The design has historically been characterized by the habit to think at the project as an inventive act that builds something additional to the existing reality. An idea incompatible with the idea of Central European project as an act intended to change the reality, directing it towards a horizon of order and logic. The attitude of Italian design is to develop an original model of operation based on the interaction with the small and medium industries, with their extraordinary ability to experiment, transforming the "absence" of a unified methodology in a large internal diversification of languages and trends. It's in this way that today Italian design develops new paths and pushes its boundaries beyond the traditional ones. Knitwear is one of these new paths: the knitting project involves many aspects and it allows a high degree of intervention and testing at all levels of the production chain.

In the contemporary design scenarios knitting is a really fertile project area. Even if most of the people think about it as an old-fashioned hobby, reserved to old grannies making ugly jumpers, it's clear that today knitting is a very interesting challenge from a designer point of view.

\section{Dress design in the contemporary scenario 1}

Too often the study of dress and fashion has been undertaken with a simple iconic approach, limited to a purely aesthetic discourse between the creator and the user. In this way the analysis and consequent reading result in fashion appearing decontextualized from the mechanisms that induce its ideation, production, and consumption. The common concept of "fashion" is still centred on unrestrained consumption, beauty, luxury, elegance, and distinction: a sort of "magic world", considered by many to be ephemeral, in which "image" is the only fundamental element.

Fashion details today represent speech, a sort of continual "narration" between product and consumer. If it is true that from the 1960s onwards we no longer speak of Fashion in the singular but of Fashions in the plural and since the 80 s we no longer speak of style but of styles, always in the plural, then today we can talk about the "style details" that each brand has gradually built up. Fashion products, at least designer products, are today characterized by the ability to express content of a "cultural" kind: this has gradually become the constant characterizing element. Objects become icons that testify each culture's origin; design becomes a necessary interface between tradition and modernity. The role of design to become an engine for innovation through the reinterpretation of the local's cultures and crafts productions. In the contemporary design scenarios knitting is a really fertile project area. Even if most of the people think about it as an old-fashioned hobby, reserved to old grannies making ugly jumpers, it's clear that today knitting is a very interesting challenge from a designer point of view.

Knit design involves many aspects and allows intervention and experimentation in every part of the production chain. It's a complex project that matches an ancient know-how with design experimentation and technological innovation. Objects become icons that testify each culture's origin.

Their power is conveyed through memory. Indeed, its narrative can combine archetypical images and future suggestions within a fascinating present. This new paradigm provokes new experiences and interdisciplinary encounters, like between architecture and medicine, or between fashion and crafts.

The research, the design, the knitwear

The design of knitwear is a rather new field within the broader view of fashion design education.

Unlike the latter, it has almost never been treated as a sector that can conduct design research although in Italy, as we have seen, it represents one of the oldest manufacturing industries. Industrial research in this area is developed mainly in the spinning mills, one of the areas of the Italian manufacturing sector that still counts with different excellences in Italy; the type of search is often of industrial one, mainly applied to fibers and yarns and to their consequent performances in relation to the final product that they will become. Today, it's possible to intervene on the yarn quality, its composition, its weight to modify the hand, wearability, the comfort directly on the skin. The research may be historicalartistic, in other words it's possible to analyze a range of experiences of the past that tell certain experiments, which then became textile innovations. It is also technologic linked to the evolution of industrial machines that are used in this sector. In fact the production of knitwear, unlike clothing fabric, appears directly connected and conditioned in its marketing characteristics of style, by the requirements of the available machinery and looms; therefore, Italy has been one of the leading countries in this field starting with a production made in the most part with flat knitting machines operated by hand, in 1950, passing to the great boom of the construction of electronic machines and the introduction of the circular ones, and today where electronics, combined with advanced technology, allow machines to simulate the hand processes directly on the drapes that are made mechanically. 
To speak of a textile product, then, we cannot disregard its soul, as represented by thread and the different qualities of yarn that exist; it is a product that lives in the contemporary world and, since technology has permeated this particular field as well, undergoes various treatments to increase its performance characteristics. The finishing treatments can be divided into two main groups: there are those designed to improve technical qualities such as antistatic, crease-resistant, non-shrink, anti-infiltrating, impermeability, waterproofing, fireproofing and mothproofing treatments. Or else there are those treatments that affect the appearance of the fabrics and sometimes even disguise the original material such as ironing, dyeing, scouring, felting, flocking, coating, embroidery, countergluing and lacing. Especially in the period of Italian autarchy, the development of new fibres and yarns will ensure that thoughts will turn to dressing in a different way; it will no longer be necessary, because of their total or partial absence, to wear garments made with the better-known yarns like cotton, wool or silk, but gradually innovative fabrics will be placed in the market, including those stemming from previously unknown production processes. The invention, for example, of the spinning centrifuge in 1900 provided a major contribution to the development of the processing of viscose, destined to become the world's most popular man-made fibre.

SNIA is founded in 1919 as the Società di Navigazione, Industria e Commercio, and in those years acquires control of the artificial fibres industries Anonima Viscosa Pavia, the Unione Italiana Fabbriche Viscosa in Venaria Reale and the Società Italiana Seta Artificiale, until it divested its maritime activities completely in 1929 to become one of the largest groups controlling the production of artificial fibres in the world.

SNIA Viscosa will be the producer of the first Italian casein fibre, which was even celebrated by Filippo Tommaso Marinetti in The poem of the milk outfit, 1937 will see the introduction of Cisalfa, "the new fibre for woollens which presents a number of economic solutions for the department stores that would allow a still agricultural Italy to dress to impress"2. From the point of view of "fashion", knitwear will become an area of research for Luisa Spagnoli, one of the first women to play a very important role in this area: in the suburb of Santa Lucia in Perugia she will open her home-workshop in which she will create a fibre known as Spagnoli Angora, a successful experiment in the autarchic period in which the fulcrum lies in the "production process": the angora rabbits are not killed or even shorn, but lovingly combed to derive the Angora wool which will then be spun to become the highquality material for beautiful shawls, boleros and sweaters.

With nylon and polyester we witness another major innovation in the way of dressing and producing clothing: with nylon, introduced in Italy in the late forties by Rhodiatoce, a subsidiary of the Montecatini Group, the use and relationship with the body of women's stockings changed. The invention of the polyester in the fifties radically changed the textile industry by introducing fabrics that were easy to maintain and possess a "memory", that is, that are able to quickly resume their original shape. As underlined by Garofoli (1991, p. 44), polyester, whether pure or in a blend with cotton, and wool and in silk uses, gave rise to the first "wash and wear" clothes because they needed almost no ironing.

\section{Re-Active H2Dry and K-Wool H2Dry}

Nature has given us the best wool. Human ingenuity has transformed it into something unique, able to push the performance boundaries of a pure wool yarn. Re-Active H2Dry and K-Wool H2Dry are an ideal synthesis between artisan craftsmanship and technological research, two yarns of superior technical properties, with an excellent aesthetic quality3 .

Technological research passes through here too, from the desire to turn a thread into something unique and special; Re-Active is a yarn in pure superfine wool (17.5 micron), and K-Wool is a yarn in extra-fine pure wool (19.5 micron) both born from the continuous research developed by Zegna Barney Lane Borgosesia in its laboratories. H2Dry is a special treatment that allows the skin to breathe, whisking moisture away from the body. The two yarns together with this particular treatment permit knitted fabrics to be worn more comfortably directly against the skin, whether a polo shirt or a dress shirt, because the surface of the body stays perfectly dry, giving the garment a surprising drying speed.

Knitwear is certainly one sector that understands the need to understand the 'spirit of the times' and thus it is the thread, the soul of any knit, not to mention any fabric that we wear, which is the very subject of research for Zegna Baruffa Lane Borsosesia: "The tests performed in the laboratory at the Turin Polytechnic, according to the international Moisture Management Test AATCC 195-2009, demonstrated the exceptional ability of Re-Active and K-Wool to pull moisture from the body to the exterior of the garment". If the wool itself already has the right features, Re-Active H2Dry and K-Wool H2Dry enhance it by creating wrinkle-free garments. For example, a knit packed in a suitcase for a long trip stays intact and remains fresh, with no traces of wrinkles or creases. The innate elasticity of the fibers, enhanced by H2Dry finishing, make the two yarns even more flexible and lighter both in classic and more elaborate workings, rendering the fabric more comfortable and wearable; a practical and concrete advantage for every day clothing: every garment is always ready to be worn.

Just like how in the early '70s, technological research allowed for the creation of Cashwool ${ }^{\circledR}$ (extra-fine Merino wool) currently stocked in 300 colors, today H2Dry represents the future of the knits, expressing contemporary style and addressing unspoken needs and desires of a customer that is constantly evolving. 
The companies Ledal S.p.A. and Sinterama S.p.A., active with technological research on fibres, produced reflective and phosphorescent yarns. The first developed Lamè Litelife, a security yarn that ensures visibility in the dark and is ideal for casual wear.

It's made with films containing glass pearls that act as spherical lenses bouncing incoming light to the original light source: a yarn to keep in mind while designing outerwear, suits, sportswear in general.

The second has obtained a phosphorescent yarn, the Ghost, that is charged in a wide spectrum of visible light and even more through ultraviolet light and is discharged in the dark by emitting a visible light. The intrinsic phosphorescence of Ghost, thanks to a new generation additive, is ten times more brilliant and durable than normal phosphorescent pigments to zinc sulphate. It has several uses in clothing and decor.

These yarns are used in the development of a Bachelor's degree Thesis at Politecnico di Milano, within the Knit Design Lab. (Figures 1, 2, 3)

\section{Dryarn}

Dryarn is a special polypropylene microfiber produced exclusively by Aquafil, an Italian company specialized in research, development and production of synthetic fibres since 1970. Thanks to its unique structure, Dryarn is a light yarn (10 km of yarn weigh only $1 \mathrm{gram}$ ), it floats on water, is $100 \%$ recyclable, waterproof and temperature controller, which makes it particularly suitable for athletes, especially in intensive activities and muscle strain. Dryarn ensures a high level of hygiene: it cannot be attacked by moths, insects or other microorganisms, secondly, thanks to the high surface tension of microfiber, the yarn is able to trap mold or bacteria. That's why, in addition to being adopted as yarn for Italian national ski team athletes' uniforms, it has been used for creating gowns and other work wear for the medical field.

\section{Solvron}

Solvron is a synthetic yarn belonging to the family of polyvinyl alcohol (PVA) yarns exclusively produced by Nativy Co., Ltd. of Tokyo which dissolves when immersed in hot or boiling water without the aid of chemical agents.

This feature makes Solvron an ideal yarn to intervene in the critical phases of the process of garment construction, and to solve some of the problems that occur during processing. It can be used as support when blended with low resistance yarns, which tend to break if machined by themselves. Once all the fabrics are done without breaking, Solvron dissolves and remains the original yarn. It may be useful for speeding up operations that usually require manual intervention, such as the assembly of various pieces of a sock through the elimination of the separation, necessary for the achievement at the machine: if Solvron is used for separation it won't be needed to remove it by hand but just dip your socks in hot water.

Immerging Solvron in cold water, and gradually raising the temperature, will make it shrink without breaking or flaking. Only when the water reaches the required temperature Solvron will melt.

\section{Conclusion}

"Excellence is achieved when good taste, technique and experience are able to express with balance and stability the qualities of a selected raw material". Alberto Barberis-Canonico

Knitwear Design is a quite new area of Fashion Design. Unlike the latter it has never been treated as a research field even if, in Italy, it represents one of the most ancient industrial sectors: the collections of Italian brands like Missone, Malo, Falconeri are 100\% made by knitwear and in the latest years knitwear has a rate of approximately $35-40 \%$ in the collections of several Italian and international brands.

The research in this area comes mainly from spinning industries: this manufacturing sector has yet different realities of excellence in Italy, especially in geographic areas around Biella, in Piemonte, Carpi, in Emilia Romagna, Valdagno, in Veneto.

It could be an industrial kind of research, which aims to intervene on the quality of yarns, on its meshes, its touch, its fit and comfort when put directly on the skin.

Who is then responsible for projecting (from the Latin "pro-jacere", "throw over") from the present known, with knitwear design has one more tool: innovation is sometimes told as something different from everything there was before. Think instead that, in this sector, the innovation can also be given by changing the point of view; if Proust said that "the real voyage of discovery consists not in seeking new landscapes, but in having new eyes" then paraphrasing him we could say that in the fashion industry the real discovery is not to present a collection of clothes different from season to season but is to understand how to move from tradition, in this case the Italian one, through the tools and design methodologies to innovate "from inside" a complex and multifaceted sector. Innovation is not a revolution, it's a way to deal with all sorts of problems day after day. The goal is to make it even more efficient than it already is, providing cutting-edge standards of excellence. 
Innovation so as knowledge to reinterpret the past by reading the zeitgeist; innovation as the ability to act on materials, starting from their characteristics, and then upset them and create something unexpected. Finally, innovation through research in the project Culture without constraints or prejudices.

\section{Notes}

1. Many of the parts of this paper come from different theoretical reflections published by the author in: Sul filo dell'innovazione. Progetti e visioni tra moda, tessuti, filati, in (catalogo della mostra) AA. VV. Textile Vivant. Percorsi, esperienze e ricerche del textile design, Editoriale Silvana Spa, 2014.

With Martina Motta, Teaching Knitwear Design: Design Practice for Traditional Manual Knowledge Innovation, 10th International Conference on Design Principles and Practices and the Design Principles and Practices knowledge community, PUC Rio de Janeiro, 2016. With Silvia Amorosino, Narrative design objects. Towards a multidimensional society valorizing the "heritage". "Sealing on a DressBone" project, 1st International Conference on Environmental Design 06th/07th of March 2015, Agrigento. With Martina Motta, Knit Design. Ovvero progettare con un filo, Ottagono, $\mathrm{N}^{\circ} 268$, Marzo 2014, Milano.

With Federico Poletti, Costanza Rinaldi, Maglieria Made in Italy Knitwear. Stories and Talks, Silvana Editoriale, Milano, 2016,

2. B. Giordani Aragno, "Storie sul filo di lana", in V.A., Maglifico! 50 anni di straordinaria maglieria Made in Italy, Skira, Milan 2012, p. 18.

3. In "The H2dry By Zegna Barney Lane Borgosesia", Conti G.M., Technological Research as Applied to Yarns, in Conti G.M., Poletti F., Rinaldi C., (2016), Maglieria Made in Italy Knitwear. Stories and Talks, Silvana Editoriale, Milano, p. 189

\section{References}

Aa.Vv., Maglifico! (2012). 50 anni di straordinaria maglieria Made in Italy. Milano: Skira.

Annichiarico, S. (2009). Tremate tremate, le streghe son tornate, in Aa.Vv. Milano: Dritto Rovescio, Electa Mondadori.

Caoci, A.; Lai, F. (2007). Gli oggetti culturali. L'artigianato tra estetica, antropologia e sviluppo locale. Milano:

Franco Angeli. Conti, G.; Motta, M. (2014). Knit Design. Ovvero progettare con un filo, Ottagono, $\mathrm{N}^{\circ}$ 268, Marzo. Conti, G. M.; Colonetti, A. (2014). Design \& Moda. Firenze - Milano: Giunti Editore S.p.a.

Conti, G. M., Vacca F. (2008). Traditional Textile on Fashion Design. New path for experience. Paper for "Changing the Change. Design, Visions Proposals and Tools: Torino 2008", Proceedings "Changing the Change. Design, Visions Proposals and Tools", Umberto Allemandi \& C.

Conti, G. M.; Zanolla Mancini, A. S. (2014). Strategic Analysis on the Multan Handicrafts. Springer, Springer international Publishing Switzerland.

Davis, F. (1993). Moda: cultura, identità, linguaggio. Bologna: Baskerville.

Dorfles, G. (2008). La (nuova) moda della Moda. Milano: Costa\&Nolan.

Durante, V. (2004). Sportsystem, the fashion performance. Caerano San Marco (TV); Danilo Zanetti Editore.

Fiorani, E. (2005). I panorami del contemporaneo. Milano: Lupetti.

Fiorani, E. (2000). II mondo degli oggetti. Milano: Lupetti.

Frassine, R.; Rubertelli, M.; Soldati, M. G. (2008). Textile design. Materiali e tecnologie. Milano: Franco Angeli. Kennedy, S. (2010). Vintage Swimwear, a History of Twentieth-Century Fashions. Londra: Carlton Books Ltd. Micelli, S. (2011). Futuro artigiano. Venezia: Marsilio.

San Martin, M. (2010). Materiali innovativi per la moda. Modena: Logos.

McGregor, S. Traditional Scandinavian Knitting. Lusekofte: Dover Publications Inc.

Paris, I. (2006). Oggetti cuciti. L'abbigliamento pronto in Italia dal primo dopoguerra agli anni settanta. Milano:

Franco Angeli. Poiret, D. E. (2003). Tennis Fashion. NY, USA: Assouline Publishing; s.n.

Udale, J. (2014). Fashion Knitwear. Laurence King Publishing.

Abstract: In the actual globalized context in which the cross-fertilization among disciplines and different fields of project mixes together forms, systems and processes, Knitwear Design can make the difference in the production and in the consumption of the products.

Actually they are real insights on the various issues that characterize this area; today designing in very specific areas such as Italian knitwear, made of artists, designers, spinners, companies, perpetually poised between tradition and manual industrial product, makes research a really complicated challenge.

In contemporary scenarios knitwear design is a complex process, combining ancient techniques of traditional knowledge with experimentation and technological innovation. It's a challenge that feeds the curiosity and the desire to seek more.

Key words: Knitwear Design - Cross Fertilization - Innovation - Design Thinking - Yarns - Materials.

Resumo: No contexto globalizado de hoje, em que a fertilização cruzada entre diferentes disciplinas e áreas de projeto é misturada gerando formas, sistemas e processos, Design de tecidos pode fazer a diferença na produção e consumo de produtos. 
$\mathrm{Na}$ realidade, são ideias reais sobre várias questões que caracterizam esta área. Atualmente o projeto em áreas muito específicas, como ponto de design de tecido italiano por artistas, designers, spinners, empresas continuamente entre tradição e manual do produto industrial, torna a pesquisa um desafio realmente difícil.

Em cenários de design contemporâneo, tricô é um processo complexo que combina técnicas tradicionais antigos de conhecimento através da experimentação e inovação tecnoló- gica. É um desafio que alimenta a curiosidade e o desejo de procurar ainda mais.

Palavras chave: confecção de malhas - a fertilização cruzada - inovação - design thinking - fios - materiais.

Material for knitwear: a new contemporary design scenario fue publicado de la página 125 a página134 en Cuadernos del Centro de Estudios de Diseño y Comunicación №70 